\title{
Temperature-dependent thermal expansivities of silicate melts: The system anorthite-diopside
}

\author{
R. KNOCHE, D. B. DINGWELL, and S. L. WEBB \\ Bayerisches Geoinstitut, Universität Bayreuth, W-8580 Bayreuth, Germany
}

(Received May 7, 1991; accepted in revised form November 20, 1991)

\begin{abstract}
The temperature-dependent thermal expansivities of melts along the join anorthite-diopside have been determined on glassy and liquid samples using a combination of calorimetry, dilatometry, and Pt double bob Archimedean densitometry.

Supercooled liquid volumes and molar thermal expansivities were determined using scanning calorimetric and dilatometric measurements of properties in the glass region and their behavior at the glass transition. The extraction of low-temperature liquid molar expansivities from dilatometry/calorimetry is based on an assumed equivalence of the relaxation of volume and enthalpy at the glass transition using a method developed and tested by WEBB et al. (1992). This method corrects for transient effects at the glass transition which can lead to serious overestimates of liquid thermal expansivity from "peak" values. Superliquidus volumes were determined using double Pt bob Archimedean densitometry at temperatures up to $1650^{\circ} \mathrm{C}$.

The resulting data for liquid volumes near glass transition temperatures $\left(810-920^{\circ} \mathrm{C}\right)$ and at superliquidus temperatures $\left(1400-1650^{\circ} \mathrm{C}\right)$ are combined to yield thermal expansivities over the entire supercooled and stable liquid range. The molar expansivities are, in general, temperature dependent. The temperaturedependence of thermal expansivity increases from anorthite to diopside composition. The thermal expansivity of anorthite is essentially temperature independent, whereas that of diopside decreases by $\cong 50 \%$ between 800 and $1500^{\circ} \mathrm{C}$, with the consequence that the thermal expansivities of the liquids in the anorthite-diopside system converge at high temperature.
\end{abstract}

\section{INTRODUCTION}

THE DENSITY OF SILICATE melts during rock-forming processes is a critical factor in the efficiency of crystal-melt fractionation, which ultimately gives rise to the diversity of igneous rocks. Accordingly, the experimental determination of melt densities has been the subject of considerable investigation in the geological sciences (see summary to 1970 by BOTTINGA and WEILL, 1970; BOTTINGA et al., 1982; Mo et al., 1982; STEIN et al, 1986; LANGE and CARMICHAEL, 1987; DINGWELL et al., 1988). These investigations have invariably been conducted in the superliquidus regime where problems of crystallization do not occur and high viscosities can often be avoided. Igneous petrogenesis is, however, an overwhelmingly subliquidus subject. The processes leading to both erupted and intruded products of igneous fractionation occur at temperatures down to the solidus, and in disequilibrium cases, at subsolidus temperatures.

The glassforming ability of many silicate melts is evidence of the fact that crystallization can be avoided to subsolidus temperatures if the conditions of cooling are appropriate. These melts can be investigated, just above the glass transition, as true supercooled liquids (i.e., in metastable or local equilibrium) at temperatures and time scales that preclude significant crystallization or liquid-liquid immiscibility. Use of these low-temperature metastable liquid property data, in combination with superliquidus liquid property data for individual melt properties, provides a wide temperature range over which the liquid behavior can be interpolated. Several studies of the viscosity and heat capacity of silicate melts have utilized this possibility to provide a much more complete description of these properties of silicate melts. The results are both quantitative and qualitative (i.e., theoretical) improvements in our understanding of silicate melts (e.g., RICHET et al., 1986). In this study we move a step further in the analysis of glass transition behavior to derive molar thermal expansivity data for metastable liquids. In this way, our knowledge of subliquidus melt densities, extant during igneous petrogenesis, is significantly improved.

\section{METHODS}

The compositions used in this investigation lie along the join anorthite $\left(\mathrm{CaAl}_{2} \mathrm{Si}_{2} \mathrm{O}_{8}\right)$-diopside $\left(\mathrm{CaMgSi}_{2} \mathrm{O}_{6}\right)$, representing one of the limiting joins of the albite-anorthite-diopside system. This system is of interest as it has been historically applied as a model for basalt petrogenesis (e.g., phase equilibria: BOWEN, 1915; SCHAIRER and YODER, 1960; OSBORN and TAIT, 1952; KUSHIRO, 1973; thermochemistry: WEILL et al., 1980; NAVRoTSKY et al., 1980; 1989; viscosity: SCARFE et al., 1983; SCARFE and CRONIN, 1986; TAUBER and ARNDT, 1987; ultrasonic wave velocities: RIVERS and CARMICHAEL, 1987; shock wave equation of state: RIGDEN et al., 1988, 1989).

The glassy starting materials were obtained from M. Rosenhauer, Universitat Göttingen. Their method of preparation is described by TAUBER (1987). Chemical analyses of these glasses are provided in Table 1 along with the details of analytical methods. The stoichiometric compositions are also included in Table 1 for comparison. These previously prepared glasses were chosen for the present investigation because viscosity data have been obtained on this system over a wide temperature range by TAUBER and ARNDT (1987) using the micropenetration method and also because a reconnaissance differential thermal analysis of these glasses has been made by KNOCHE (1990).

The dilatometric and calorimetric investigations were performed on glass cylinders ( $25 \mathrm{~mm}$ long $\times 8 \mathrm{~mm}$ diameter) using methods identical to those described by WEBB et al. (1992). The calorimetry was performed in continuous scanning mode using a Setaram ${ }^{*}$ HTC instrument. The heat flow was recorded during heating runs of $5^{\circ} \mathrm{C} /$ 
Table 1. Chemical composition of glasses (wt \%).

\begin{tabular}{|c|c|c|c|c|c|c|c|c|c|}
\hline & $\mathrm{SiO}$ & & $\mathrm{Al}_{2} \mathrm{O}_{3}$ & $\mathrm{Na}_{2} \mathrm{O}$ & $\mathrm{CaO}$ & $\mathrm{MgO}$ & $\mathrm{FeO}$ & $\mathrm{K}_{2} \mathrm{O}$ & $\Sigma$ \\
\hline AN100 & $\begin{array}{l}43.0 \\
43.2\end{array}$ & * & $\begin{array}{l}35.1 \\
36.7\end{array}$ & 0.01 & $\begin{array}{l}20.5 \\
20.2\end{array}$ & 0.10 & 0.02 & 0.005 & 98.7 \\
\hline AN7ODI30 & $\begin{array}{l}46.3 \\
45.8 \\
46.3 \\
46.3\end{array}$ & $\begin{array}{l}* \\
\ddagger \\
\$ \\
\dagger\end{array}$ & $\begin{array}{l}26.5 \\
26.8 \\
26.8 \\
27.5\end{array}$ & $\begin{array}{l}0.14 \\
0.17\end{array}$ & $\begin{array}{l}21.3 \\
23.0 \\
21.0 \\
21.6\end{array}$ & $\begin{array}{l}4.77 \\
5.08 \\
4.9 \\
4.66\end{array}$ & $\begin{array}{l}0.09 \\
0.10\end{array}$ & $\begin{array}{l}0.05 \\
0.05\end{array}$ & $\begin{array}{r}99.2 \\
101.0 \\
99.0\end{array}$ \\
\hline AN50DI50 & $\begin{array}{l}47.3 \\
48.5 \\
47.4 \\
48.6\end{array}$ & $\begin{array}{l}* \\
\ddagger \\
\$ \\
\dagger\end{array}$ & $\begin{array}{l}19.9 \\
20.8 \\
20.6 \\
20.6\end{array}$ & $\begin{array}{l}0.12 \\
0.13\end{array}$ & $\begin{array}{l}25.0 \\
23.1 \\
23.1 \\
22.7\end{array}$ & $\begin{array}{l}6.88 \\
7.27 \\
7.0 \\
8.15\end{array}$ & $\begin{array}{l}0.08 \\
0.10\end{array}$ & $\begin{array}{l}0.02 \\
0.03\end{array}$ & $\begin{array}{l}99.3 \\
99.9 \\
98.1\end{array}$ \\
\hline AN2ODI 80 & $\begin{array}{l}52.3 \\
52.5 \\
53.0 \\
52.5\end{array}$ & $\begin{array}{l}* \\
\ddagger \\
\$ \\
t\end{array}$ & $\begin{array}{l}8.70 \\
8.50 \\
9.0 \\
8.91\end{array}$ & $\begin{array}{l}0.08 \\
0.08\end{array}$ & $\begin{array}{l}24.3 \\
25.1 \\
23.3 \\
24.5\end{array}$ & $\begin{array}{l}14.1 \\
14.7 \\
13.8 \\
14.1\end{array}$ & $\begin{array}{l}0.09 \\
0.11\end{array}$ & $\begin{array}{l}0.06 \\
0.06\end{array}$ & $\begin{array}{r}99.6 \\
101.1 \\
99.1\end{array}$ \\
\hline DI100 & $\begin{array}{l}56.2 \\
56.0 \\
55.5\end{array}$ & $\begin{array}{l}* \\
\ddagger \\
t\end{array}$ & $\begin{array}{l}0.19 \\
0.29\end{array}$ & $\begin{array}{l}0.16 \\
0.18\end{array}$ & $\begin{array}{l}25.9 \\
26.5 \\
25.9\end{array}$ & $\begin{array}{l}17.3 \\
17.8 \\
18.6\end{array}$ & $\begin{array}{l}0.02 \\
0.02\end{array}$ & $\begin{array}{r}0.007 \\
<0.001\end{array}$ & $\begin{array}{r}99.8 \\
100.8\end{array}$ \\
\hline
\end{tabular}

* analysis by electron microprobe, Bayerisches Geolnstitut, operating conditions $15 \mathrm{kV}$ accelerating voltage, $15 \mathrm{nA}$ current on brass, $20 \mathrm{sec}$ count times using a $10 \mu \mathrm{m}$ defocussed beam, standards wollastonite (Ca), diopside (Mg), albite (Si, Na), orthoclase (K), $\mathrm{Fe}_{2} \mathrm{O}_{3}(\mathrm{Fe})$, spinel (Al).

+ Stoichiometric (theoretical) compositions

* instrumental analysis, $\mathrm{Si}$ and $\mathrm{Al}$ by "spectral photometer", $\mathrm{Ca}, \mathrm{Mg}, \mathrm{Na}$ and $K$ by atomic absorption, Feo by wet chemical titration, standards granite (Si, $\mathrm{Al}, \mathrm{Na}, \mathrm{Ca}, \mathrm{Mg}, \mathrm{Fe}, \mathrm{K}$ ), andesite (Si, $\mathrm{Al}, \mathrm{Na}, \mathrm{Mg}, \mathrm{K}$ ), granodiorite (Si, Al, $\mathrm{Na}, \mathrm{Ca}, \mathrm{Mg}, \mathrm{K}$ ), diabase (Al, $\mathrm{Na}, \mathrm{Ca}, \mathrm{Mg}, \mathrm{K}, \mathrm{Fe}$ ), peridotite (Al, $\mathrm{Mg}, \mathrm{Fe}$ ), basalt (Al, K), dunite (Al, Fe) (Mielke, 1984, 1985, 1988, personal communication).

\&-ray fluorescence analysis (Ca, Si), electron microprobe (Mg, Al) see Tauber and Arndt (1987).

min on glasses that had been previously cooled at cooling rates of 1 , 2,5 and $10^{\circ} \mathrm{C} / \mathrm{min}$. The calorimeter is calibrated regularly against a geometrically identical cylinder of sapphire, using the heat capacity data of RoBie et al. (1979). The heat capacity data for the $5 / 5$ (cooling-rate/heating-rate) runs are presented in Table 2. The heat capacities are estimated to have a precision of $\pm 2.5 \%$ at $1 \sigma$, based on the four runs performed for each sample. The measured heat capacities for the anorthite and diopside glasses are within error of those determined by STEBBins et al. (1982), STEBbins et al. (1983), and RICHET and BOTTINGA (1984).

The dilatometry was performed using a Netzsch ${ }^{\circledR}$ TMA 402 quartzrod dilatometer. The samples, their thermal history, and the scanning rates were those used in the calorimetry measurements. This instrument has been calibrated against sapphire (NBS sheet 732) and the molar expansivities have an accuracy of $\pm 3 \%$ at $1 \sigma$, calculated from the errors in the measurements of the thermal expansivity of the standard and the sample.

The high-temperature densitometry was performed using the apparatus described by DINGWELL et al. (1988) employing the double Pt bob Archimedean method. Densities obtained using this method have a precision of $\pm 0.2 \%$ and reproduce the best value for molten $\mathrm{NaCl}$ within this precision (JANZ, 1980). Room-temperature densities of the glass cylinders were measured using Archimedean buoyancy in toluene and have a precision of $\pm 0.2 \%$.

\section{THEORY}

The theory of our procedure for obtaining relaxed liquid molar expansivity data from a combination of scanning calorimetry and dilatometry has been presented in full by WEBB et al. (1992) and is reviewed here. When a silicate glass is heated across the glass transition region, a time-dependent response of its physical properties occurs. The unrelaxed, glassy values of volume and enthalpy are replaced by equilibrium, liquid values over a finite period of time. The relaxation behavior of melt volume, enthalpy, and viscosity in the glass transition region has been intensively investigated for several compositions of interest to the glass industry (e.g., SCHERER, 1986). Further quantitative models of structural relaxation have been constructed (NARAYANASWAMY, 1971; MoYNiHAN et al., 1976; SCHERER, 1984) to reproduce the details of the time-dependent response of melt properties in the glass transition interval. The models are completely general, describing the response of property $\Phi$ as a function of previous cooling rate and experimental heating rate. 
The properties of a silicate melt depend upon the ambient temperature $T$ and the configuration or structure of the melt. Silicate glasses quenched from liquids preserve a configuration that can be approximated to the equilibrium structure of the liquid at some fictive temperature, denoted $T_{\mathrm{r}}$ (ToOL and EICHLIN, 1931). To describe, in general, the rclaxed (liquid) or unrelaxed (glassy) properties of a silicate melt we need to specify the temperature and the fictive temperature of the melt. For a liquid, the structure is in equilibrium and thus $T_{\mathrm{f}}$ equals $T$ (see Fig. 1). Upon cooling of the liquid into the glass transition region, the structure of the melt begins to deviate from equilibrium (i.e., $T_{\mathrm{f}}$ deviates from $T$ ). This deviation results ultimately in a temperature independence of $T_{f}$ at low temperatures, corresponding to the frozen structure of the glassy state. Upon subsequent reheating through the glass transition interval, the value of $T_{\mathrm{f}}$ once again assumes that of $T$ and liquid values of melt properties are observed. The path of the value of the property taken during reheating is, however, different from that observed during cooling. Due to the finite rate of equilibration available for relaxation at the onset of the glass transition region, there is an overshoot in the transient value of the melt property (i.e.y the fictive temperature of the structure is lower than the temperature, $T_{\mathrm{f}}<T$; DINGWELL and WEBB, 1990).

The temperature derivative of the properties of a glass and a liquid (e.g., molar heat capacity $(d H / d T)$ and molar thermal expansivity $(d V / d T)$ ) can be used to describe the temperature derivative of $T_{\mathrm{f}}$. To do this, the temperature derivative of any property in the glass transition interval (e.g., enthalpy, volume) is normalized with respect to the temperature derivative of the liquid and glassy properties. This normalized temperature derivative, which is equal to $d T_{\mathrm{f}} / d T$, must equal zero for the glass ( $T_{f}$ is constant) and 1 for the liquid ( $T_{r}$ equals $T$ ). The correct description of melt properties in the glass transition region thus becomes the task of devising an algorithm for the temperature dependence of the fictive temperature, and this has been done for example by MOYNIHAN et al. (1976).

The temperature derivative of the fictive temperature $T_{\mathrm{f}}$ at a temperature $T^{\prime}$ is related to the temperature dependence of the macroscopic property $\Phi$ by

$$
\left.\frac{d T_{\mathrm{f}}}{d T}\right|_{r^{\prime}}=\frac{\left.\left[(\partial \Phi / \partial T)-(\partial \Phi / \partial T)_{\mathrm{B}}\right]\right|_{T^{\prime}}}{\left[(\partial \Phi / \partial T)_{e}-(\partial \Phi / \partial T)_{g} \|_{T_{\mathrm{f}}}\right.}
$$

where the subscripts " $\mathrm{e}$ " and " $\mathrm{g}$ " are for the liquid (equilibrium) and the glassy values of the property (MOYNIHAN et al., 1976). In the present study, the property $\Phi$ is taken to be enthalpy $I$, and volume $V$. Assuming the equivalence of volume and enthalpy relaxation behavior, Eqn. (1) can then be rewritten as

$$
\left.\frac{d T_{\mathrm{f}}}{d T}\right|_{r^{\prime}}=\frac{c_{\mathrm{p}}\left(T^{\prime}\right)-c_{\mathrm{pg}}\left(T^{\prime}\right)}{c_{\mathrm{pe}}\left(T_{\mathrm{f}}\right)-c_{\mathrm{pg}}\left(T_{\mathrm{f}}\right)}=\frac{\frac{d V(T)}{d T}-\left.\frac{d V_{\mathrm{g}}(T)}{d T}\right|_{T^{\prime}}}{\frac{d V_{\mathrm{e}}(T)}{d T^{\prime}}-\left.\frac{d V_{\mathrm{g}}(T)}{d T}\right|_{T_{\mathrm{f}}}}
$$

Thus, in the glass transition region, the behavior of any temperature-dependent property of a glass can be predicted from the known behavior of another temperature-dependent property if the relaxation behavior of the two properties is equivalent. It has been noted by REKHSON et al. (1971) and SASABE et al. (1977) that the time scales of volume and viscosity, and refractive index and enthalpy relaxation, respectively, in silicate melts are indistinguishable. HiGGins et al. (1972) also found that ionic and mechanical relaxation have the same activation energy and timescale in $\mathrm{Na}_{2} \mathrm{Si}_{3} \mathrm{O}_{7}$ melt. In the above equation relating $c_{\mathrm{p}}$ and thermal expansivity $d V / d T$, the unknown parameter is the thermal expansivity of the relaxed liquid at temperature $T^{\prime}$ which is some $50^{\circ} \mathrm{C}$ above the glass transition temperature.

We recover the liquid molar thermal expansivity from the dilatometric trace by normalizing both the scanning calorimetric and dilatometric data. Due to the lack of relaxed thermal expansivity data, the calorimetric and dilatometric data have been normalized by

$$
\Phi^{\prime}(T)=\frac{\Phi(T)-\Phi_{\mathrm{B}}(T)}{\Phi_{\mathrm{p}}-\Phi_{\mathrm{g}}(T)}
$$

where the subscripts " $p$ " and "g" refer to peak and glassy values. The relaxed value of thermal expansivity can now be generated from the peak and extrapolated glassy values of thermal expansivity; the volume and coefficient of volume thermal expansion $\alpha_{v}[1 / V(d V / d T)]$ of the melt can also be calculated.

Setting the peak values from the calorimetric and dilatometric data to be equal requires the assumption that insignificant viscous deformation is recorded by the dilatometer at temperatures up to the peak temperature. WEBB et al. (1992) have shown that the contribution to the apparent thermal expansion due to viscous deformation becomes significant $(>1 \%)$ only at temperatures $5-15^{\circ} \mathrm{C}$ above the peak temperatures for the present heating rate.

Critical to the success of our assumptions in treating the calorimetric and dilatometric data has been the use of a single sample and the same set of experimental conditions to obtain heat capacity and thermal expansivity data. Small changes in composition or fictive temperature of a silicate melt can strongly influence relaxation behavior. We wish to stress that the above method can only be applied to calorimetric and dilatometric data obtained on the same sample using identical thermal histories. It is only this internal consistency that permits the use of the assumption of the equivalence of the enthalpy and volume relaxation behavior.

\section{RESULTS}

A typical set of calorimetric and dilatometric data is presented in Fig. 2 for the composition AN50DI50. The effect of viscous deformation in the liquid region of the dilatometric trace is clearly visible. The normalized comparison of relaxation in the dilatometric and calorimetric traces is illustrated in Fig. 3. Expansivities of the supercooled liquids derived from the earlier mentioned normalization procedure are presented in Table 3 . The thermal expansivity data of the glasses have been fitted to first-order polynomials, with the resulting molar volume equations being presented in Table 4. The room temperature and superliquidus density data are presented in Table 5. 
Table 2. Measured $c_{p}\left(\mathrm{~J} / \mathrm{g}^{\circ} \mathrm{C}\right)$ data for glasses and liquids. Cooling rate

$5^{\circ} \mathrm{C} / \mathrm{min}$; heating rate $5^{\circ} \mathrm{C} / \mathrm{min}$.

\begin{tabular}{|c|c|c|c|c|c|}
\hline $\mathrm{T}\left({ }^{\circ} \mathrm{C}\right)$ & AN100 & AN7ODI 30 & AN50DI50 & AN20DI80 & DI100 \\
\hline 300 & & 1.0279 & 1.0117 & 0.9971 & 1.0043 \\
\hline 310 & & 1.0338 & 1.0147 & 1.0033 & 1.0105 \\
\hline 320 & & 1.0378 & 1.0180 & 1.0054 & 1.0148 \\
\hline 330 & & 1.0380 & 1.0216 & 1.0098 & 1.0208 \\
\hline 340 & & 1.0487 & 1.0273 & 1.0163 & 1.0230 \\
\hline 350 & & 1.0608 & 1.0351 & 1.0195 & 1.0251 \\
\hline 360 & & 1.0651 & 1.0383 & 1.0270 & 1.0321 \\
\hline 370 & & 1.0696 & 1.0437 & 1.0328 & 1.0374 \\
\hline 380 & & 1.0750 & 1.0515 & 1.0365 & 1. 0403 \\
\hline 390 & & 1.0813 & 1.0559 & 1.0432 & 1.0402 \\
\hline 400 & 1.0243 & 1.0862 & 1.0609 & 1.0479 & 1. 0460 \\
\hline 410 & 1.0225 & 1.0885 & 1.0658 & 1.0486 & 1.0559 \\
\hline 420 & 1.0249 & 1.0902 & 1.0673 & 1.0487 & 1.0716 \\
\hline 430 & 1.0293 & 1.0931 & 1.0705 & 1.0536 & 1.0800 \\
\hline 440 & 1.0310 & 1. 1012 & 1. 0757 & 1.0607 & 1. 0604 \\
\hline 450 & 1.0350 & 1.1058 & 1.0830 & 1.0617 & 1.0309 \\
\hline 460 & 1.0377 & 1.1063 & 1.0842 & 1.0674 & 1.0457 \\
\hline 470 & 1.0445 & 1.1135 & 1.0897 & 1.0702 & 1.0745 \\
\hline 480 & 1.0390 & 1.1178 & 1.0944 & 1.0749 & 1.0947 \\
\hline 490 & 1.0437 & 1.1209 & 1.0928 & 1.0821 & 1. 1048 \\
\hline 500 & 1.0498 & 1.1253 & 1.0970 & 1.0878 & 1.1170 \\
\hline 510 & 1.0633 & 1. 1269 & 1.0969 & 1.0951 & 1. 1263 \\
\hline 520 & 1.0617 & 1. 1274 & 1. 1038 & 1.0953 & 1. 1409 \\
\hline 530 & 1.0538 & 1.1390 & 1.1111 & 1.0988 & 1.1469 \\
\hline 540 & 1.0535 & 1.1427 & 1.1102 & 1.1055 & 1. 1460 \\
\hline 550 & 1.0662 & 1. 1476 & 1.1153 & 1.1093 & 1. 1601 \\
\hline 560 & 1.0759 & 1.1512 & 1. 1214 & 1. 1195 & 1. 1619 \\
\hline 570 & 1.0769 & 1. 1562 & 1. 1241 & 1.1235 & 1. 1681 \\
\hline 580 & 1.0919 & 1. 1635 & 1.1312 & 1.1290 & 1. 1862 \\
\hline 590 & 1.0901 & 1.1679 & 1.1331 & 1. 1346 & 1. 1857 \\
\hline 600 & 1.0885 & 1.1740 & 1. 1408 & 1. 1350 & 1.1856 \\
\hline 610 & 1.0946 & 1.1758 & 1. 1471 & 1.1390 & 1.1911 \\
\hline 620 & 1. 1014 & 1.1778 & 1.1490 & 1.1467 & 1. 2027 \\
\hline 630 & 1.1101 & 1.1818 & 1. 1552 & 1.1494 & 1.2023 \\
\hline 640 & 1.1114 & 1.1874 & 1.1577 & 1.1576 & 1.1775 \\
\hline 650 & 1. 1068 & 1.1934 & 1.1610 & 1. 1551 & 1.1804 \\
\hline 660 & 1. 1085 & 1.1958 & 1.1612 & 1.1553 & 1.1980 \\
\hline 670 & 1. 1208 & 1.2007 & 1.1687 & 1.1652 & 1. 2341 \\
\hline 680 & 1. 1273 & 1. 2029 & 1.1700 & 1.1734 & 1.2676 \\
\hline 690 & 1. 1256 & 1.2213 & 1.1909 & 1.1917 & 1.2969 \\
\hline 700 & 1.1239 & 1. 2254 & 1. 1972 & 1.2295 & 1. 3646 \\
\hline 710 & 1. 1.386 & 1.2307 & 1.2102 & 1.2933 & 1. 4856 \\
\hline 720 & 1. 1340 & 1. 2328 & 1.2297 & 1.4125 & 1.6536 \\
\hline 730 & 1.1290 & 1.2412 & 1.2679 & 1.5781 & 1.7955 \\
\hline 740 & 1.1352 & 1.2603 & 1. 3482 & 1.6653 & 1.7860 \\
\hline 750 & 1. 1308 & 1.2889 & 1.4675 & 1.6214 & 1. 7402 \\
\hline 760 & 1. 1271 & 1. 3473 & 1.6078 & 1.5824 & 1.7085 \\
\hline 770 & 1.1373 & 1. 4491 & 1.6494 & 1.5622 & 1.6929 \\
\hline 780 & 1.1428 & 1.5768 & 1.6060 & 1.5550 & 1.6821 \\
\hline 790 & 1.1441 & 1.6727 & 1. 5735 & 1.5502 & 1.6749 \\
\hline 800 & 1.1480 & 1.6637 & 1.5546 & & 1.6782 \\
\hline 810 & 1.1716 & 1.6322 & 1. 5476 & & \\
\hline 820 & 1.1979 & 1.6058 & 1.5468 & & \\
\hline 830 & 1.2224 & 1. 5981 & & & \\
\hline 840 & 1.2880 & 1.5970 & & & \\
\hline 850 & 1. 3931 & 1.6022 & & & \\
\hline 860 & 1.5135 & & & & \\
\hline 870 & 1.6108 & & & & \\
\hline 880 & 1.5905 & & & & \\
\hline 890 & 1.5457 & & & & \\
\hline 900 & 1. 5235 & & & & \\
\hline
\end{tabular}


Table 2. (Cont inued)

\begin{tabular}{llllll}
\hline \hline $\mathrm{T}\left({ }^{\circ} \mathrm{C}\right)$ & AN100 & AN70DI30 & AN50DI50 & AN20DI80 & DI100 \\
\hline 910 & 1.5155 & & & \\
920 & 1.5104 & & & \\
930 & 1.5068 & & & \\
940 & 1.5041 & & & & \\
950 & 1.5148 & & & & \\
& & & & & \\
peak & & & & & \\
temperature & $868^{\circ} \mathrm{C}$ & $792^{\circ} \mathrm{C}$ & $769^{\circ} \mathrm{C}$ & $740^{\circ} \mathrm{C}$ & \\
\end{tabular}

The volume data for the supercooled liquids (derived from the dilatometry / calorimetry) and for the superliquidus liquids are presented in Table 6 . The molar volumes have been combined and regressed against temperature using first- and second-order polynomials. The results of the least-squares regressions are reproduced in Table 7 (see also Fig. 4.), together with the root mean squared deviations. The value of the supercooled $d V / d T$ obtained from the dilatometry/calorimetry comparison is used to constrain the low-temperature slope of the curve fitted to the volume data. The inclusion of a temperature derivative for the molar expansivity of diopside liquid reduces the RMSD to within the error estimates of the volume data. In contrast, the anorthite volume data are described within error by a constant value of molar expansivity. The relaxed liquid volume data from dilatometry and the superliquidus volume data for diopside and anorthite are presented in Fig. 4 along with the polynomial fits to the data. The temperature dependence of the fitted values of molar expansivity increase smoothly with increasing diopside content. For an illustration of this, the temperature-dependent thermal expansivity $d V / d T$ and the coefficient of volume thermal expansion $\alpha_{v}[1 / V(d V / d T)]$ resulting from the regressions of Table 6 have been plotted in the temperature range of input data (approx. $800-1600^{\circ} \mathrm{C}$ ) in Fig. 5. (In this plot the temperature-dependent thermal expansivity for anorthite is included for consistency of the comparison.)

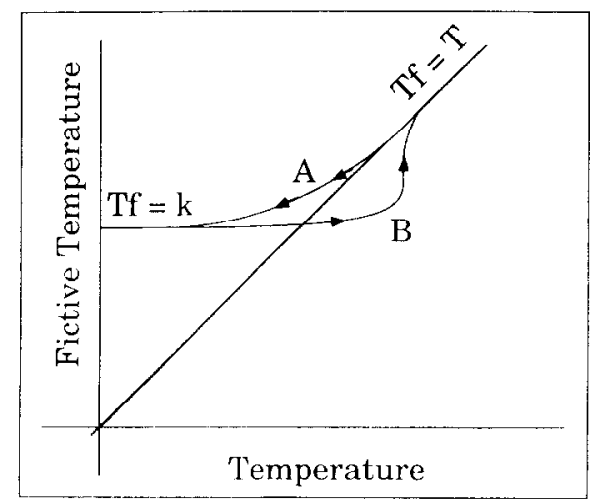

FIG. 1. The cooling (a) and reheating (b) paths of a silicate melt in temperature-fictive temperature space.

\section{DISCUSSION}

The present glass densities, $2.704 \pm 0.003 \mathrm{~g} \mathrm{~cm}^{-3}$ for anorthite and $2.851 \perp 0.003 \mathrm{~g} \mathrm{~cm}^{-3}$ for diopside, are within the range of those previously obtained for anorthite $\left(2.700 \mathrm{~g} \mathrm{~cm}^{-3}\right.$ by BERMAN et al., 1942; $2.64 \mathrm{~g} \mathrm{~cm}^{-3}$ by CUKIERMAN and UHLMANN, $1973 ; 2.701 \mathrm{~g} \mathrm{~cm}^{-3}$ by ARNDT and HÄBERLE, $1973 ; 2.66 \mathrm{~g} \mathrm{~cm}^{-3}$ by SEIFERT et al., $1982 ;$ and $2.704 \mathrm{~g} \mathrm{~cm}^{-3}$ by TANIGUCHI, 1989) and for diopside $\left(2.846 \mathrm{~g} \mathrm{~cm}^{-3}\right.$ by BERMAN et al., 1942; $2.870 \mathrm{~g} \mathrm{~cm}^{-3}$ by TANIGUCHI, 1989). The densities of glasses are dependent on thermal history, and this, combined with slight compositional variations, precludes a closer comparison of the glass data.

The superliquidus density of diopside liquid has been investigated by LICKO and DANEK (1982) using the falling sphere method and by LANGE and CARMICHAEL ( 1987) and TaniguCHi (1989) using the double Pt bob method. The results of LANGE and CARMICHAEL (1987) and TANIGUCHI (1989) agree well with our diopside density data while those of LICKO and DANEK (1982) are 1\% lower. The density of melts on the anorthite-diopside join has been investigated by TANiguchi (1989). Our results deviate from his with increasing anorthite content.

The reasons for this discrepancy for anorthite are not clear, but at $1580^{\circ} \mathrm{C}$, the I ANGE and CARMICHAEL (1987) calculation scheme yields a value $\left(2.5649 \mathrm{~g} \mathrm{~cm}^{-3}\right)$ which lies between the result of this investigation $(2.6007 \pm 0.01214 \mathrm{~g}$ $\left.\mathrm{cm}^{-3}\right)$ and the value $\left(2.538 \mathrm{~g} \mathrm{~cm}^{-3}\right)$ of TANIGUCHI (1989). Further data are needed in the $\mathrm{CaO}-\mathrm{Al}_{2} \mathrm{O}_{3}-\mathrm{SiO}_{2}$ system to resolve this discrepancy.

TANIGUCHI (1989) has investigated the anorthite-diopside system using dilatometry. He used "peak" values of thermal expansivities (the maximum in the $d V / d T$ curve) for the liquid at the glass transition with the result that the values obtained were consistently too high to reproduce the hightemperature volumes of his liquids. His Fig. 5 illustrates, for example, the contrast between a "peak" coefficient of thermal expansion of $240 \times 10^{6}{ }^{\circ} \mathrm{C}^{-1}$ vs. a coefficient of thermal expansion of $125 \times 10^{6}{ }^{\circ} \mathrm{C}^{-1}$ obtained from a polynomial fit to density at the "peak" temperature, for diopside. ARNDT and HÄBERLE (1973) investigated the thermal expansion of an anorthite glass using a procedure similar to TANIGU. $\mathrm{CHI}$ to determine the thermal expansivity above the glass transition 

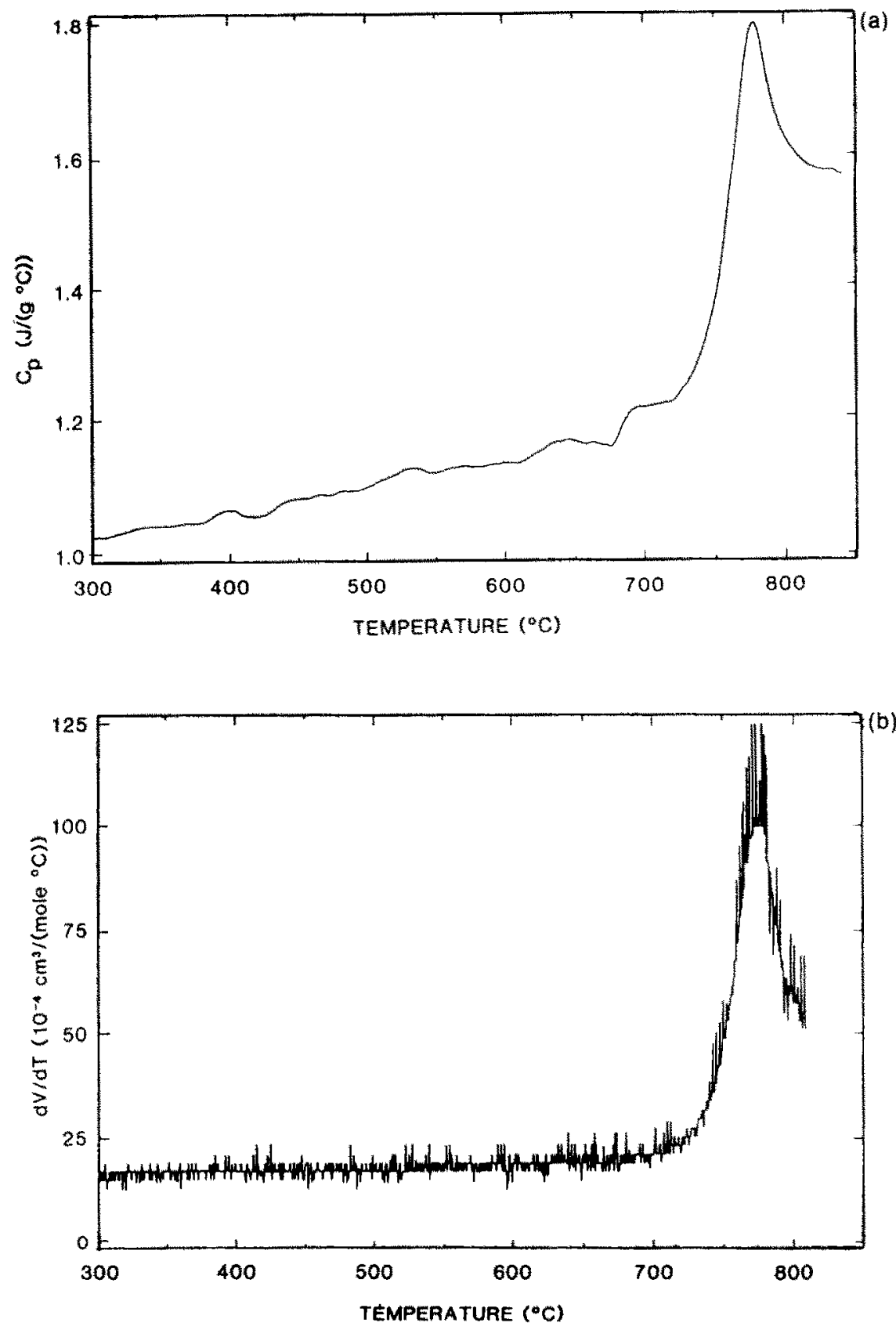

FIG. 2. Calorimetric (a) and dilatometric (b) traces for AN50DI50. The effect of viscous deformation due to body forces in the upper viscoelastic region of the dilatometric trace is visible.

In the present study our measured thermal expansivities near $T_{\mathrm{g}}$ are consistent with the values obtained from our volume fits as seen in Table 3 where our measured and fitted values of the coefficient of thermal expansion for diopside at $810^{\circ} \mathrm{C}$ are $125 \times 10^{-6}{ }^{\circ} \mathrm{C}^{-1}$ and $123 \times 10^{-6}{ }^{\circ} \mathrm{C}^{-1}$, respectively.

We wish to stress the agreement between the expansivity data obtained from dilatometry/calorimetry and those obtained from the fits to the combined (high- and low-temperature) melt volume data (Table 3 ). This agreement removes the discrepancy posed by the TANIGUCHI (1989) data and improves confidence in the prediction of lowntemperature melt densities.
An inspection of Fig. 4 indicates that extrapolation of diopside volume data either up or down temperature from the segments of the volume curve covered by either method, will result in serious overestimates of liquid volume. The extrapolation of high-temperature volumes and expansivity to low temperature yields a $3 \%$ error. This diserepancy lies outside the accuracy of multicomponent calculation schemes presently available (e.g., LANGE and C.ARMICHAFI., 1987). Clearly, a much more complete investigation of the temperature dependence of liquid expansivity is required to incorporate this correction in such schemes.

It has been demonstrated for a number of silicate melts that calorimetric or dilatometric peak temperatures represent 


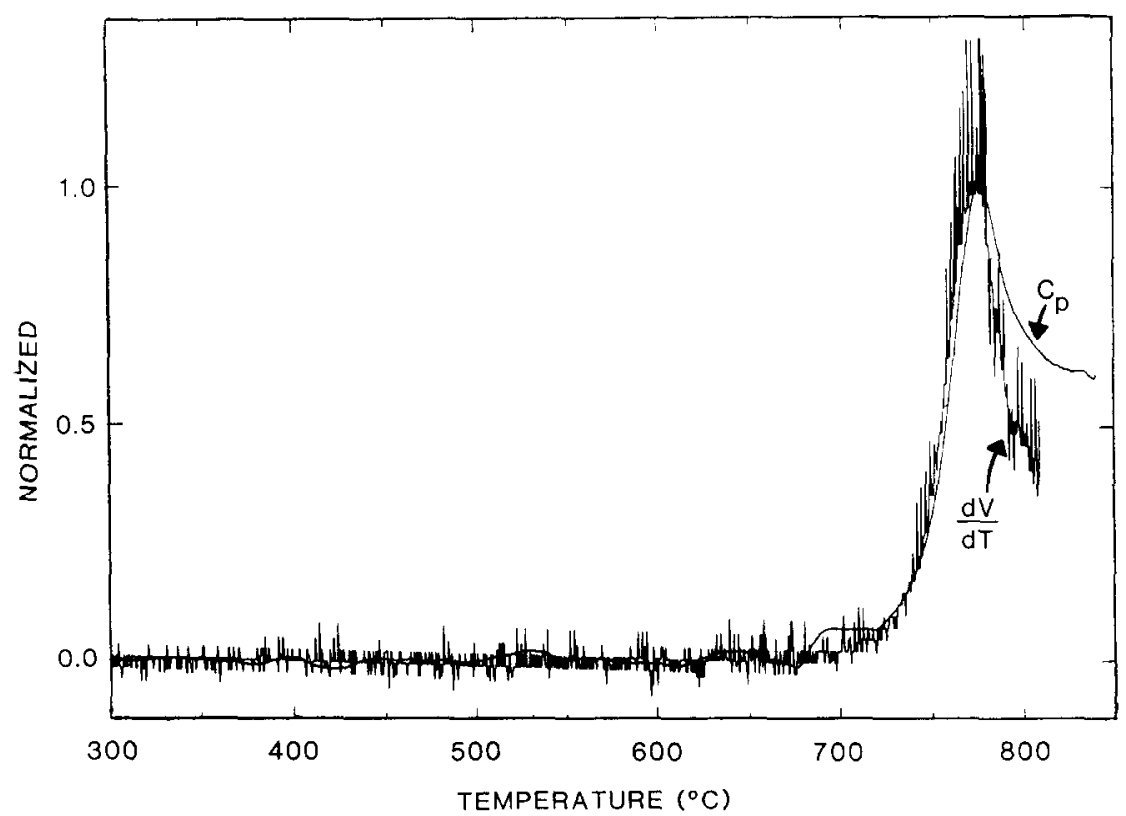

FIG. 3. The method of normalization of the dilatometric and calorimetric traces illustrated for AN50DI50.

temperatures of constant viscosity vs. compositıon, or "isokoms" (SCHERER, 1986). This is because the temperaturedependent processes of volume and enthalpy relaxation are strongly linked to those controlling shear flow (DINGWELL and WEBB, 1989, 1990). The time scale can be estimated from the Maxwell relation (DINGWELL and WEBB, 1989), which relates the ratio of shear viscosity and shear modulus to the shear relaxation time. Literature data for the shear

Table 3. Measured and fitted values of $d V / d T$ and $\alpha_{v}[1 / V(d V / d T)]$ for the supercooled liquids.

\begin{tabular}{|c|c|c|c|c|c|}
\hline & $\frac{d v^{m}}{d T}$ & $\frac{d v^{f}}{d T}$ & $\alpha_{v}^{m}$ & $\alpha_{y}^{f}$ & Temperature \\
\hline & $10^{-4} \mathrm{~cm}^{3}$ & mole $e^{-1} \cdot{ }^{\circ} \mathrm{C}^{-1}$ & $10^{-6}$ & $C^{-1}$ & ${ }^{\circ} \mathrm{C}$ \\
\hline AN100 & $54.4 \pm 2.1$ & $40.7 \pm 31.6$ & $52.0 \pm 2.0$ & $38.9 \pm 29.3$ & 920 \\
\hline AN70DI30 & $65.0 \pm 1.7$ & $55.6 \pm 15.4$ & $67.4 \pm 1.8$ & $57.7 \pm 15.6$ & 860 \\
\hline AN50DI50 & $70.5 \pm 3.9$ & $74.5 \pm 3.2$ & $78.0 \pm 4.3$ & $82.3 \pm 3.3$ & 830 \\
\hline AN2ODI 80 & $87.8 \pm 2.3$ & $90.0 \pm 0.1$ & $106.2 \pm 2.8$ & $108.9 \pm 0.8$ & 810 \\
\hline DI100 & $96.9 \pm 1.9$ & $95.3 \pm 3.4$ & 125. $1 \pm 2.6$ & $123.0 \pm 4.0$ & 810 \\
\hline
\end{tabular}

\footnotetext{
superscript $m$ refers to measured expansivity from normalization procedure.
-superscript $f$ refers to fitted expansivity at the same temperature obtained from the 2nd order polynomial fit of volumes.


Table 4. Molar volume of glasses.

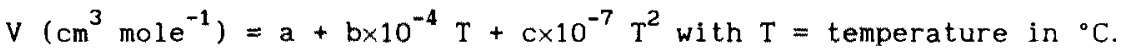

\begin{tabular}{lcccc}
\hline & $\mathrm{a}$ & $\mathrm{b}$ & $\mathrm{c}$ & Temperaturc $\left({ }^{\circ} \mathrm{C}\right)$ \\
\hline AN100 & 102.87 & 15.00 & 2.94 & $20-780$ \\
AN70DI30 & 94.94 & 14.72 & 4.50 & $20-710$ \\
AN50D150 & 88.83 & 16.53 & 3.57 & $20-680$ \\
AN20D180 & 81.01 & 15.54 & 5.07 & $20-660$ \\
DI100 & 75.93 & 14.25 & 8.75 & $20-660$ \\
\hline
\end{tabular}

cooling/heating rate: $5 / 5\left({ }^{\circ} \mathrm{C} / \mathrm{min}\right)$

Table 5. Molar weight $(g)$ and glass and liquid densities $\left(\mathrm{g} \mathrm{cm}^{-3}\right)$.

\begin{tabular}{|c|c|c|c|c|c|c|c|}
\hline \multirow[b]{2}{*}{ Temperature $\left({ }^{\circ} \mathrm{C}\right)$} & \multirow[b]{2}{*}{20.5} & \multicolumn{3}{|c|}{ densities } & \multirow[b]{2}{*}{1572} & \multirow[b]{2}{*}{1622} & \multirow[t]{2}{*}{ molar weight } \\
\hline & & 1422 & 1447 & 1522 & & & \\
\hline AN100 & 2.704 & - & - & - & 2.6033 & 2.5954 & 278.211 \\
\hline AN70DI30 & 2.735 & - & 2.6197 & 2.6107 & - & - & 259.714 \\
\hline AN50DI50 & 2.784 & 2.6293 & - & 2.6168 & - & - & 247.382 \\
\hline AN2ODI 80 & 2.824 & 2.6324 & - & 2.6202 & - & - & 228.885 \\
\hline DI 100 & 2.851 & 2.6340 & - & 2.6178 & - & 2.6010 & 216.553 \\
\hline
\end{tabular}

Table 6. Observed molar liquid volumes $\left(\mathrm{cm}^{3}\right.$ mole $\left.\mathrm{e}^{-1}\right)$

\begin{tabular}{lrrrrrr}
\hline Temperature $\left({ }^{\circ} \mathrm{C}\right)$ & & 1422 & 1447 & 1522 & 1572 & 1622 \\
\hline AN100 & $104.466\left(920^{\circ} \mathrm{C}\right)$ & - & - & - & 106.869 & 107.194 \\
AN70D130 & $96.445\left(860^{\circ} \mathrm{C}\right)$ & - & 99.139 & 99.480 & - & - \\
AN50DI50 & $90.439\left(830^{\circ} \mathrm{C}\right)$ & 94.087 & - & 94.536 & - & - \\
AN20D180 & $82.632\left(810^{\circ} \mathrm{C}\right)$ & 86.949 & - & 87.354 & - & - \\
DI100 & $77.504\left(810^{\circ} \mathrm{C}\right)$ & 82.215 & - & 82.723 & - & 83.258 \\
& & & & & & \\
\hline
\end{tabular}


Table 7. Molar liquid volumes.

$V\left(\mathrm{~cm}^{3}\right.$ mole $\left.\mathrm{e}^{-1}\right)=\mathrm{a}+\mathrm{b} \times 10^{-3} \mathrm{~T}+\mathrm{c} \times 10^{-6} \mathrm{~T}^{2}$ with $\mathrm{T}=$ temperature in ${ }^{\circ} \mathrm{C}$.

\begin{tabular}{lcccc}
\hline & $\mathrm{a}$ & $\mathrm{b}$ & $\mathrm{c}$ & $\sum^{\text {(residua })^{2}}$ \\
\hline AN100 & $100.36(1.52)$ & $4.93(2.56)$ & $-0.47(1.01)$ & 0.0172 \\
& $101.07(0.05)$ & $3.74(0.05)$ & & 0.0176 \\
AN70DI30 & $90.50(0.70)$ & $8.32(1.27)$ & $-1.61(0.53)$ & 0.0057 \\
& $92.61(0.04)$ & $4.52(0.04)$ & & 0.0108 \\
AN50DI50 & $82.75(0.14)$ & $11.05(0.26)$ & $-2.17(0.11)$ & 0.0004 \\
& $85.50(0.04)$ & $5.98(0.05)$ & & 0.0143 \\
AN20D180 & $73.17(0.03)$ & $14.37(0.06)$ & $-3.32(0.03)$ & 0.0001 \\
& $77.26(0.07)$ & $6.70(0.07)$ & & 0.0345 \\
DI100 & $67.79(0.15)$ & $14.47(0.28)$ & $-3.05(0.121)$ & 0.0016 \\
& $71.72(0.09)$ & $7.23(0.09)$ & & 0.0988 \\
\hline
\end{tabular}

moduli of diopside and anorthite glasses (BANSAL and DOREMUS, 1986) allow us to confirm this approximation for the anorthite-diopside system as illustrated in Fig. 6. The viscosity-temperature relationships of melts on the anorthitediopside join are reproduced from TAUBER and ARNDT (1987). The calorimetric/dilatometric peak temperature for each composition has been plotted on the corresponding viscosity-temperature relationship. The resulting array of points describes an isokom. The similar values of shear modulus for diopside and anorthite melts (BANSAL and DOREMUS, 1986) and the isokom obtained in Fig. 6 lead to the conclusion

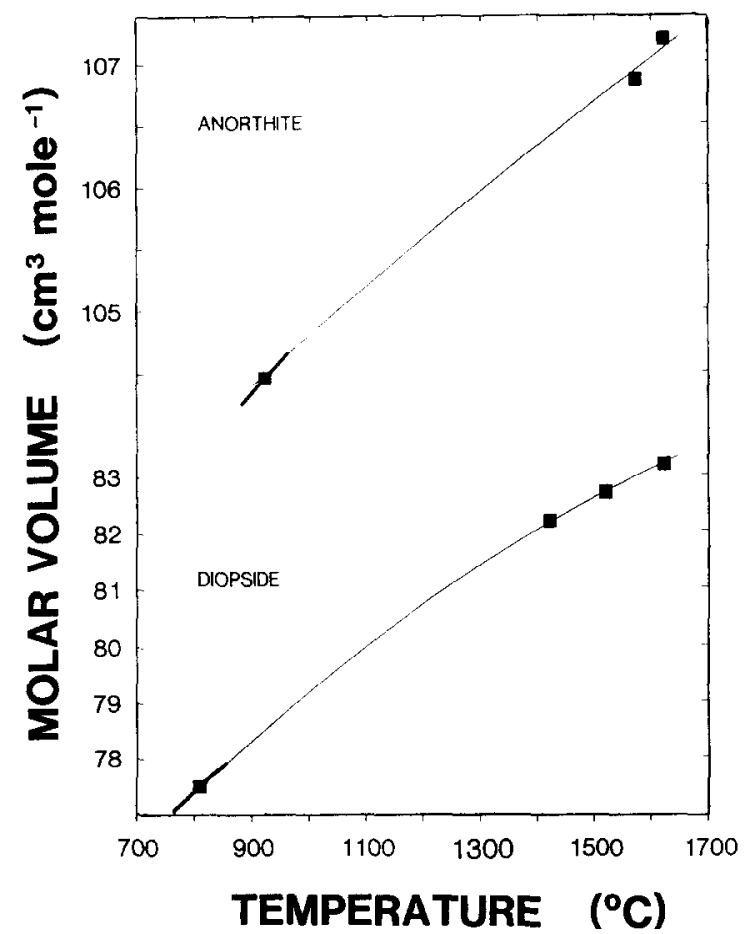

Fig. 4. Relaxed liquid volume data from dilatometry and densitometry for anorthite and diopside. that enthalpy, volume, and shear relaxation vary sympathetically across the anorthite-diopside join and confirm the approximation of the Maxwell relation as a source of shear rclaxation times. The glass transition, consistently measured
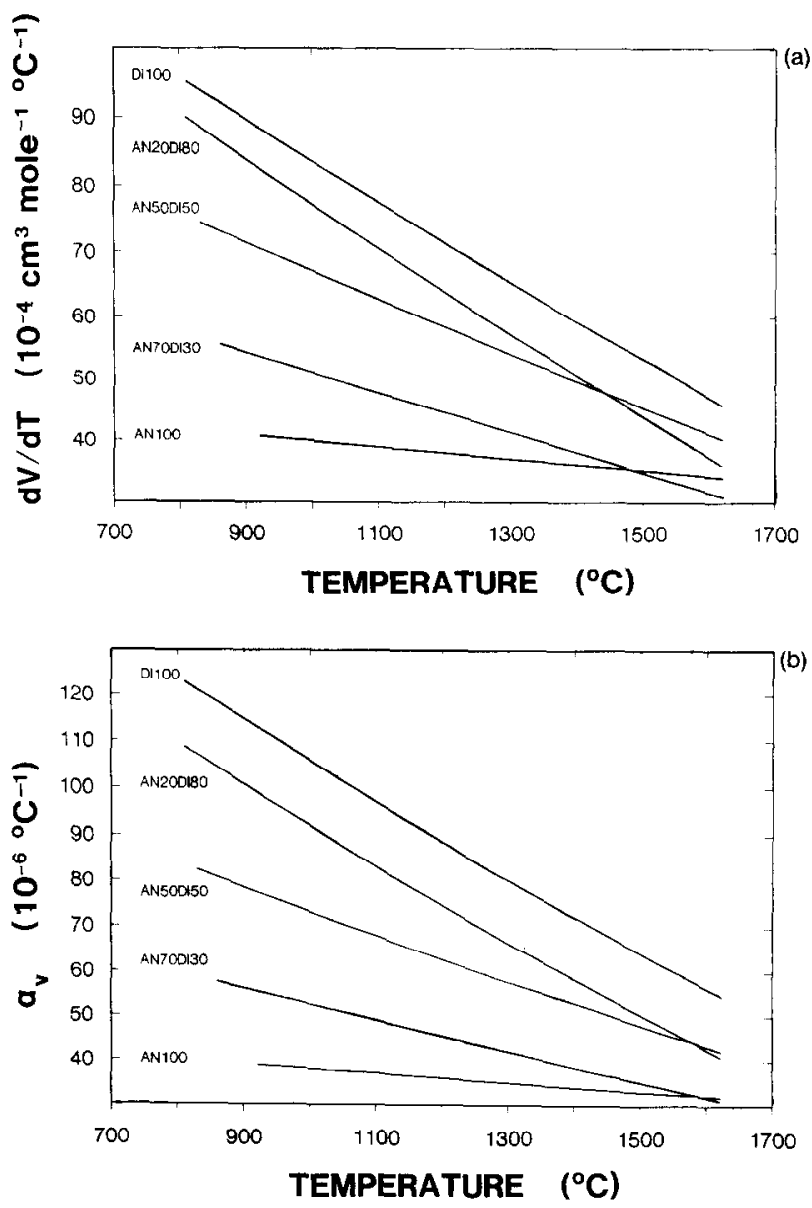

FIG. 5. Temperature dependence of (a) $d V / d T$ derived from the fits to high- and low-temperature volumes and (b) $\alpha_{v}[1 / V(d V / d T)]$ derived from the fits to high- and low-temperature volumes. 


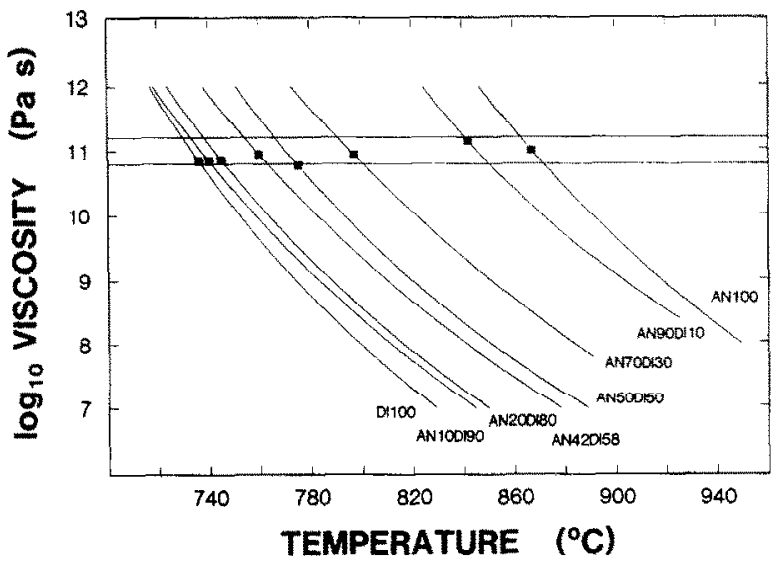

FrG . 6. Comparison of peak temperature and viscosity along the diopside-anorthite join. The glass transition temperature $T_{\mathrm{g}}$ approximates an isokom.

and described in silicate melts, approximates an isokom (e.g., RICHET, 1984).

The viscosity of diopside and anorthite melts exhibit very similar curvatures when plotted vs. temperature (Fig. 6). RICHET (1984) has interpreted this non-Arrhenian nature according to the configurational entropy theory of viscous relaxation (ADAM and GIBBS, 1965). In this theory it is the temperature dependence of the configurational entropy which parameterizes the non-Arrhenian nature of the temperature dependence of viscosity. The extant data on the configurational entropy of silicate melts, obtained by thermodynamic paths through the crystal and melting (RICHET, 1984) and by low-temperature adiabatic data for the configurational entropy of the frozen structure of the glass at the glass transition temperature (RICHET et al., 1986), confirm the applicability of the configurational entropy model where sufficient data exist for a rigorous test.

An alternative model is based on the concept of unoccupied or "free" volume in the liquid structure (e.g., COHEN and GREST, 1979). Although it is difficult to visualize the manner in which "free" volume could increase with pressure, necessary to explain the negative pressure dependence of liquid viscosity (e.g., SCARFE et al., 1987), this model has been advocated for the present system (TANIGUCHI, 1989). Here we wish to point out that the apparent contrast between similar (subparallel) viscosity-temperature relationships for diopside and anorthite (RICHET, 1984) and very dissimilar temperature dependencies of thermal expansion for these liquids (this study) appear to point to a detachment of the temperature dependence of volume from the temperature dependence of the liquid viscosities.

What is the structural origin of the temperature dependence of expansivity? The difference in stoichiometry between diopside and anorthite offers several possibilities. Quenched diopside melts illustrate that there is a nonrandom distribution of nonbridging oxygens (MYSEN et al., 1982). Furthermore, this dispersion is modifying-cation ( $\mathrm{Ca}$ or $\mathrm{Mg}$ ) specific. Thus, any change in the distribution of $\mathrm{Ca}$ vs. $\mathrm{Mg}$ in the melt should result in a change in the distribution of nonbridging oxygens. A second possibility is temperaturedependent coordination changes of cations. Tetrahedral co ordination of $\mathrm{Mg}$ (average coordination number of 4.7 \pm 0.3 ) in high-temperature melts has been suggested by $X$ ray spectroscopy (WASEDA, 1981).

The chemical complexity of the present join (An-Di) precludes structural conclusions at this time. Simpler systems are under investigation to elucidatc the structural origin of the temperature-dependent properties.

\section{CONCLUSION}

A method of determining supercooled liquid expansivity and molar volume just above the glass transition temperature has been applied to the anorthite-diopside system. These lowtemperature data in combination with volume data obtained from high-temperature densitometry result in the determination of thermal expansivity from just above the glass transition to about $1600^{\circ} \mathrm{C}$. The volume fits indicate, in general, a significant negative temperature dependence of the expansivity which results in a 50\% decrease in expansivity between 800 and $1500^{\circ} \mathrm{C}$ for diopside melt. This temperature dependence of expansivity decreases with anorthite content. Anorthite melt has no measurable temperature dependence of expansivity.

The present study solves an existing discrepancy between dilatometric and densitometry data. The improved precision of the method sets the stage for a detailed investigation of the composition dependence of expansivity in silicate melts.

Acknowledgments-We thank Kurt Klasinski for software development and Detlef Krausse for microprobe analyses. The calorimetry was supported by a Leibniz Preis to F. Seifert.

\section{Editorial handling: P. C. Hess}

\section{REFERENCES}

ADAM G. and GiBBS J. H. (1965) On the temperature dependence of cooperative relaxation properties in glass-forming liquids. $J$. Chem. Phys. 43, 139-146.

ARNDT J. and HÄBERLE F. (1973) Thermal expansion and glass transition temperatures of synthetic glasses of plagioclase-like compositions. Contrib. Mineral. Petrol. 39, 175-183.

BANSAL N. P. and DoREmus R. H. (1986) Handbook of Glass Propenties. Academic Press.

BERMAN H., DALY R. A., and SPICER H. C. (1942) Density at room temperature and 1 atmosphere. In Handbook of Physical Constants (ed. F, BIRCH et al.), No. 36, pp. 7-26. Geol. Soc. Amer.

BOTTINGA Y. and WEILL D. F. (1970) Density of liquid silicate systems calculated from partial molar volumes of oxide components. Amer. J. Sci. 269, 169-182.

Bottinga Y., WeILl D. F., and Richet P. (1982) Density calculations for silicate liquids: I. Revised method for aluminosilicate compositions. Geochim. Cosmochim. Acta 46, 909-919.

BOWEN N. L. (1915) The crystallization of haplobasaltic, haplodioritic and related magmas. Amer. J. Sci. 40, 161-185.

COHFN M. H. and GREST G. S. (1979) Liquid-glass transition, a free volume approach. Phys. Rev. B20, 1077-1098.

CUKIERMAN M. and UHLMANN D. R. (1973) Viscosity of liquid anorthite. J. Geophys. Res, 78, 4920-4923.

DINGWELL D. B. and WEBB S. L. (1989) Structural relaxation in silicate melts and non-Newtonian meit rheology in geologic processes. Phys. Chem. Mineral. 16, 508-516.

DingWeLL. D. B. and WEBB S. L. (1990) Relaxation in silicate melts. Eur. J. Mineral. 2, 427-449.

DingWell D. B., BREARley M., and Dickinson J. E., JR. (1988) Melt densities in the $\mathrm{Na}_{2} \mathrm{O}-\mathrm{FeO}-\mathrm{Fe}_{2} \mathrm{O}_{3}-\mathrm{SiO}_{2}$ system and the partial molar volume of tetrahedrally coordinated ferric iron in silicate melts. Geochim. Cosmochim. Acta 52, 2467-2475. 
HIGGINS T. J., MacFion P. B., and VolterRa V. (1972) Mechanical and ionic relaxation in $\mathrm{Na}_{2} \mathrm{O} \cdot 3 \mathrm{SiO}_{2}$ glass. $J_{1}$. Amer. Ceramic Soc. $55,488-491$

JANZ G. J. (1980) Molten salts data as reference data for density, surface tension, viscosity and electrical conductance. $J$. Phys. Chem. Ref. Data 9, 791-829.

KNoctre R. (1990) Untersuchungen der Glastransformationstemperatur in System Albit-Anorthit-Diopsid mit Hilfe der DTA. Diplomarbeit, Georg-August-Universität, Göttingen.

KusHIRo 1. (1973) The system diopside-anorthite-albite: Determination of compositions of coexisting phases. Camegie Inst. Wash Yearb. 72, 502-507.

LANGE R. A. and CARMICHAEL I. S. E. (1987) Densities of $\mathrm{K}_{2} \mathrm{O}$ $\mathrm{Na}_{2} \mathrm{O}-\mathrm{CaO}-\mathrm{MgO}-\mathrm{FeO}-\mathrm{Fe}_{2} \mathrm{O}_{3}-\mathrm{Al}_{2} \mathrm{O}_{3}-\mathrm{TiO}_{2}-\mathrm{SiO}_{2}$ liquids: New measurements and derived partial molar properties. Geochim. Cosmochim. Acta 51, 2931-2946.

LICKO T. and DANEK V. (1982) Densities of melts in the system $\mathrm{CaSiO}_{3}-\mathrm{CaMgSi}_{2} \mathrm{O}_{6}-\mathrm{Ca}_{2} \mathrm{MgSi}_{2} \mathrm{O}_{7}$. Phys. Chem. Glasses 23, 67-71.

Mo X., Carmichael I. S. E., Rivers M., and Stebirns J. (1982) The partial molar volume of $\mathrm{Fe}_{2} \mathrm{O}_{3}$ in multicomponent silicate liquids and the pressure-dependence of oxygen fugacity in magmas. Mineral. Mag. 45, 237-245.

MOVNnhan C. T., EASTEAL A. J, DeBolt M. A., and TUCKer J. (1976) Dependence of fictive temperature of glass on cooling rate. J. Amer Ceramic Soc. 59, 12-16.

MYSEN B. O., VIRGO D., and SEFERT F. A. (1982) The structure of silicate melts: Implications for the chemical and physical properties of natural magma. Rev. Geophys, 20, 353-383.

NARAYANASWAMY O.S. (1971) A model of structural relaxation in glass. J. Amer. Ceramic Soc 54, 491-498.

NAvrotsky A., HON R., Well D. F, and HenRy D. J. (1980) Thermochemistry of glasses and liquids in the system $\mathrm{CaMgSi}_{2} \mathrm{O}_{6}$ $\mathrm{CaAl}_{2} \mathrm{Si}_{2} \mathrm{O}_{8}-\mathrm{NaAlSi}_{3} \mathrm{O}_{8}, \mathrm{SiO}_{2}-\mathrm{CaAl}_{2} \mathrm{Si}_{2} \mathrm{O}_{8}-\mathrm{NaAlSi}_{3} \mathrm{O}_{8}$, and $\mathrm{SiO}_{2}$ $\mathrm{Al}_{2} \mathrm{O}_{3}-\mathrm{CaO}-\mathrm{Na}_{2} \mathrm{O}$. Geochim. Cosmochim. Acta 44, 1409-1423.

NAvRotsky A., ZIEGLER D., OeSTRIKE R, and MANIAR P. (1989) Calorimetry of silicate melts at $1773 \mathrm{~K}$ : Measurement of enthalpies of fusion and of mixing in the systems diopside-anorthite-albite and anorthite-forsterite. Contrib. Mineral. Petrol. 101, 122-130.

OsporN E. F. and TAIT D. B. (1952) The system diopside-forsteriteanorthite. Amer. J. Sci. (Bowen Volume), 413-433.

REkHSON S. M., BUlaEVA A. V., and MAZURIN O. V. (1971) Changes in the linear dimensions and viscosity of window glass during stabilization. Inorg. Mater. (Engl. Trans.) 7, 622-623.

RICHET P. (1984) Viscosity and configurational enthalpy of silicate melts Geochim. Cosmochim. Acta 48, 471-483.

RICHET P. and BOTTINGA Y. (1984) Anorthite, andesine, wollastonite, diopside, cordierite and pyrope: Thermodynamics of melting, glass transition, and properties of the amorphous phase. Earth Planet. Sci. Lett. 67, 415-432.

RICHET P., Robie R. A., and Hemmingway B. S. (1986) Low-temperature heat capacity of diopside glass $\left(\mathrm{CaMgSi}_{2} \mathrm{O}_{6}\right)$ : A calorimetric test of the configurational entropy theory applied to the viscosity of silicate liquids. Geochim. Cosmochim. Acta 50, 15211533.

RigDEN S., AHRENS T. J, and STOLPER E. M. (1988) Shock compression of molten silicate: Results for a model basaltic composition. J. Geophys. Res. 93, 367-382.

RIGDeN S., AHRENS T. J, and STOLPER E. M. (1989) High-pressure equation of state of molten anorthite and diopside. J. Geophys. Res. 94, 9508-9522.

Rivers M. L. and Carmichael I. S. E. (1987) Ultrasonic studies of silicate melts. J. Geophys. Res. 92, 9247-9270.
Robie R. A., Hemmingway B. S., and Fisher J. R. (1979) Thermodynamic Properties of Minerals and Related Substances at $298.15 \mathrm{~K}$ and 1 Bar (10 $\mathrm{s}$ Pascals) Pressure and at Higher Temperatures. US Govt. Printing Office.

SaSABE H., DEBOLt M. A., MaCEdo P. B., and Moynihan C. T. (1977) Structural relaxation in an alkali-lime-silicate glass. In Proceeding of the 11th International Congress on Glass, Prague, Vol. $1,339-348$.

SCARFE C. M. and CRONIN D. J. (1986) Viscosity-temperature relationships of melts at 1 atm in the system diopside-albite. Amer. Mineral. 74, 767-77.

SCARFE C. M., CRONIN D. J, Wenzel J. T, and KaUfManN D. A. (1983) Viscosity-temperature relationships at 1 atm in the system diopside-anorthite. Amer. Mineral 68, 1083-1088.

SCARFE C., M., MYSEN B. O., and Virgo D. (1987) Pressure dependence of the viscosity of silicate melts. In Magmatic Processes: Physicochemical Principles (ed. B. O. MYSEN); Geochem. Soc. Spec. Publ. 1, pp. 59-67.

SCHAIRER J. F. and YoDER H. S., JR. ( 1960) The nature of residual liquids from crystallization, with data on the system nephelinediopside-silica. Amer. J. Sci. 258A, 273-283.

SCHERER G. W. (1984) Use of the Adam-Gibbs equation in the analysis of structural relaxation. J. Amer. Ceramic Soc. 67, 504511.

SCHERER G. W. (1986) Reloxation in Glass and Composites. J. Wiley Sons.

SFIFERT F. A., MYSEN B. O, and VIRGO D. (1982) Three-dimensional network structure of quenched melts (glasses) in the system $\mathrm{SiO}_{2}-\mathrm{NaAlO}_{2}, \mathrm{SiO}_{2}-\mathrm{CaAl}_{2} \mathrm{O}_{4}$, and $\mathrm{SiO}_{2}-\mathrm{MgAl}_{2} \mathrm{O}_{4}$, Amer, J. Sci. $67,696-717$

Stebbins J. F., Weill D. F., Carmichael I, S. E., and Moret L. K. (1982) High temperature heat contents and heat capacities of liquids and glasses in the systcm $\mathrm{NaAlSi}_{3} \mathrm{O}_{8}-\mathrm{CaAl}_{2} \mathrm{Si}_{3} \mathrm{O}_{8}$. Contrib. Mineral. Petrol. 80, 276-284.

Stebiins J. F., Carmichael. I. S. E., and WeiLl. D. E. (1983) The high temperature liquid and glass heat contents and the heats of fusion of diopside, albite, sanidine and nepheline, Amer. Mineral. 68, 717-730.

SIEIN D. J., StEbrins J. F., and CARMICHAEL I. S. E. (1986) Density of molten sodium aluminosilicates. I. Amer. Ceramic Soc. 69, $396-399$.

TANIGUCHI H. (1989) Densities of melts in the system $\mathrm{CaMgSi}_{2} \mathrm{O}_{6}$ $\mathrm{CaAl}_{2} \mathrm{Si}_{2} \mathrm{O}_{8}$ at low and high pressures, and their structural significance. Contrib. Mineral Petrol. 103, 325-334.

TAUBER P. (1987) Viskositätsuntersuchungen im Modellsystem Anorthit-Albit-Diopsid. Dissertation, Eberhard-Karls-Universität, Tübingen.

TAUBER P. and ARNDT J. (1987) The relationship between viscosity and temperature in the system anorthite-diopside. Chem. Geol. 62. $71-81$.

TOOL A. Q. and EICHLIN C. G. (1931) Variations caused in the heating curves of glass by heat treatment. $J$, Amer. Ceramic $S o c$. 14, 276-308.

WASEDA Y. (1981) The structure of liquids, amorphous solids and solid fast ion conductors. Prog. Mat. Sci. 26, 1-122.

WEBB S. L., KNOCHE R, and DNGWELL D. B. (1992) Determination of silicate liquid thermal expansivity using dilatometry and calorimetry. Eur. J. Mineral. (in press).

WEILL D. F., HON R., and NAVROTSKY A. (1980) The igneous system $\mathrm{CaMgSi}_{2} \mathrm{O}_{6}-\mathrm{CaAl}_{2} \mathrm{Si}_{2} \mathrm{O}_{8}-\mathrm{NaAlSi}_{3} \mathrm{O}_{8}$ : Variations on a classic theme by Bowen. In Physics of Magmatic Processes (ed. R. B. HAR. GRaves), pp. 49-92. Princeton Univ. Press. 